\title{
Hammering Nail to the Head for Suicide; A Case Report and Literature Review
}

\author{
Intihar Amaçlı Kafaya Çivi Çakma; Olgu Sunumu ve Literatürün Gözden \\ Geçirilmesi
}

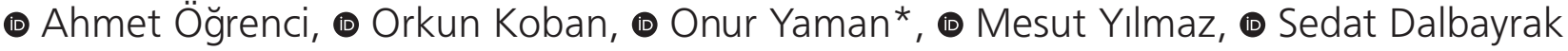 \\ Neuro Spinal Academy, Clinic of Neurosurgeon, Istanbul, Turkey \\ ${ }^{*}$ Koç University Faculty of Medicine, Department of Neurosurgeon, Istanbul, Turkey
}

Abstract

Suicide is the process that an individual ends his/her own life, and usually methods providing a quick death are chosen. The most common methods are jumping from heights and firearm shots. However, in some suicide attempts, some unusual methods are used. These can be seen in patients with psychiatric disorders such as severe depression and schizophrenia. The idea of suicide by hammering nail into the head is uncommon because it is a method that cannot lead to a quick death and cause suffering. Beside these, it does not lead to death with a single action. We present a case of a young male patient who attempted suicide with hammering nail into the head and review the literature on this subject.

Keywords: Hammering nail to head, schizophrenia, suicide
Intihar insanın kendi hayatına son vermesi işlemidir ve genellikle ölümü aniden getirecek yöntemler seçilmektedir. Bunlardan en sık olanları yüksekten atlama, ateşli silah kullanımıdır. Ancak bazı intihar şekilleri de hiç tahmin edilemeyecek yöntemlerle olabilir. Ağır depresyon, şizofreni gibi psikiyatrik hastalıkları olan hastalarda bunlar görülebilmektedir. Başına çivi çakarak intihar etme düşüncesi de sık görülen bir durum değildir. Çünkü ani ölüm getirmeyecek ve acı çekerek ölüme sebep olabilecek bir yöntemdir ve tek bir hamlede bitirelecek bir intihar girişimi değildir. Başına çekiçle çivi çakma usulü ile intihar eden genç erkek hasta olgusunu sunup literatürü gözden geçireceğiz.

Anahtar Sözcükler: Kafaya çivi çakma, şizofreni, intihar

\section{Introduction}

Suicide is the attempt of ending one's own life because of underlying psychological disorder. The type of the suicide attempt of a patient depends on the suicide devices that the patient can reach. A patient who attempt suicide may try this in a variety of ways. The patients usually choose methods which provide a quick death in only one attempt. Jumping from heights and suicide with firearms are common. The survival rate in traumatic brain injuries with firearms is very low. For this reason, headshots are common in firearm suicides. With the development of the industry, reaching to nail guns is easy and these are frequently used for suicide. However, manually hammering nails is extremely rare. There are also factors affecting survival in penetrating nail injuries to the head. Concomitant vascular injuries, hematomas and infections are determiner for survival.

\section{Case}

The patient was a 21-year-old right-handed male. He had two unsuccessful suicide attempts in his past history. He had tried to commit suicide by taking lots of drugs and tried to cut his wrists but could not succeed. He has decided to commit suicide by hammering a nail into his head. He has hammered a nail into his head (Figure 1). He was conscious when he was brought to the emergency department. There was no neurological deficit except for slight right hemiparesis (4/5). The head of the nail was seen on the scalp in the left frontoparietal region. A 10-cm nail was seen on plain $\mathrm{X}$-ray. Cranial computed tomography (CT) showed a nail in the left frontoparietal region (Figure 
2). The patient was treated with emergency surgery. Under general anesthesia, a burr hole was performed near the nail, the nail head was observed during a small circumferential craniotomy. After opening the dura mater, the nail was removed in a controlled manner. The route

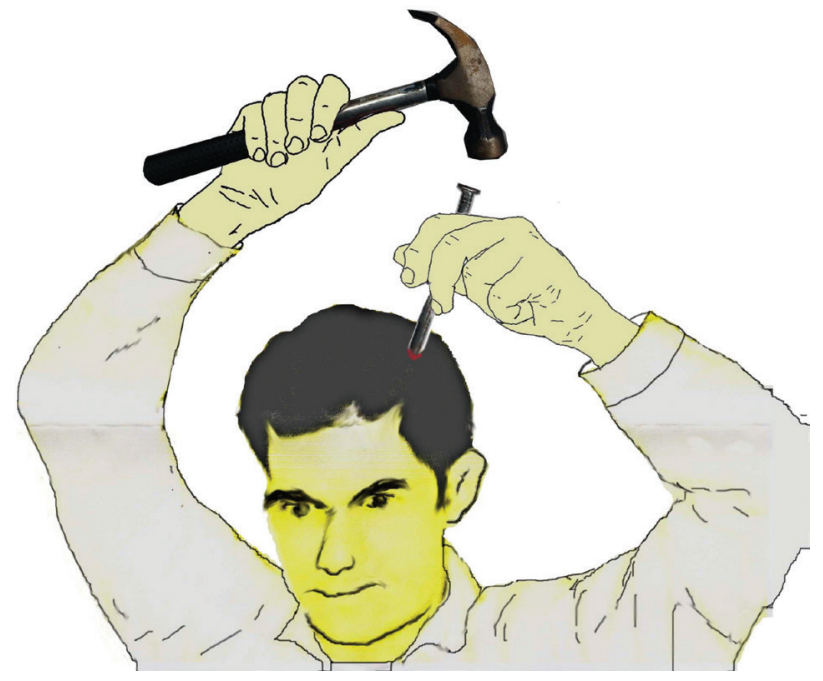

Figure 1. Demonstration of suicide attempt
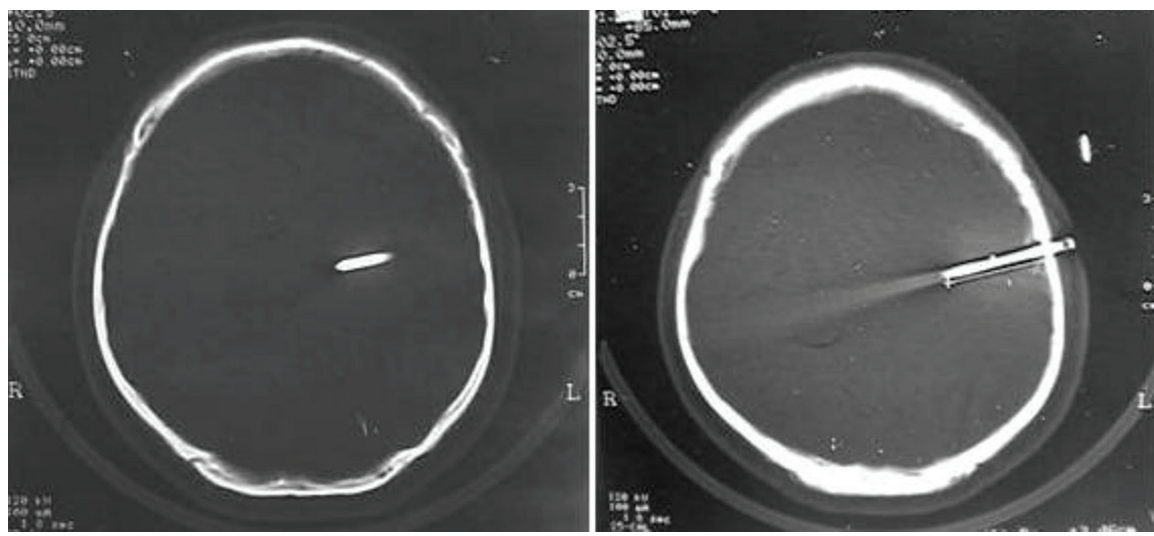

Figure 2 . The route of nail in the head is seen
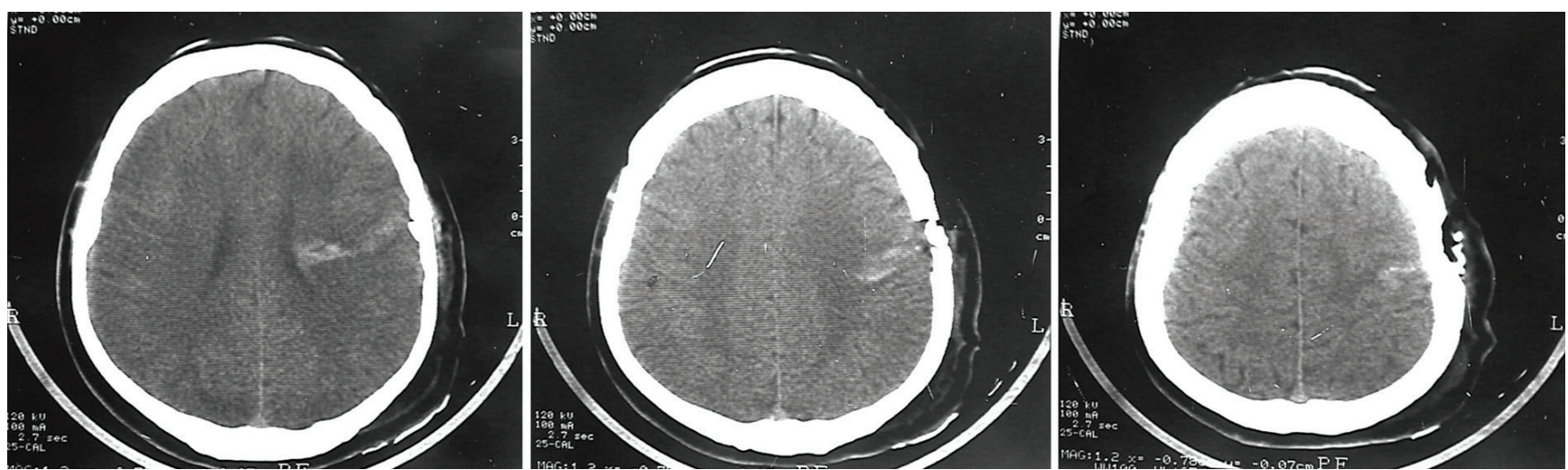

Figure 3. The hemorrhagic contusion field is seen after removal of nail of the nail in the brain was checked and the dura mater was closed with primary repair. There was no parenchymal bleeding. A follow-up CT showed the route of the nail with minimal hemorrhagic contusion (Figure 3). Postoperative course was unremarkable. His neurologic deficit recovered dramatically. The patient was referred to the psychiatry department. The patient was discharged after one month from the psychiatry department. However, he attempted suicide again by jumping from a high place three months after the discharge and lost his life.

Consent was obtained from the relatives of the patient for publication of this case report.

\section{Discussion}

Reports about injuries caused by penetrating objects such as pens, pieces of wood, knitting needles, knives or other kinds of materials are rather common in the literature (1-3). However, reports about brain injuries with penetrating objects resulting from suicide attempts are rare. In most of these injuries, automatic devices, such as nail guns, are used. Manual and self-inflicted penetrating brain injuries are less common. In the literature, there are reports of penetrating brain injuries after suicide attempt with nails, screws, awls and wires for suicide attempts (4-

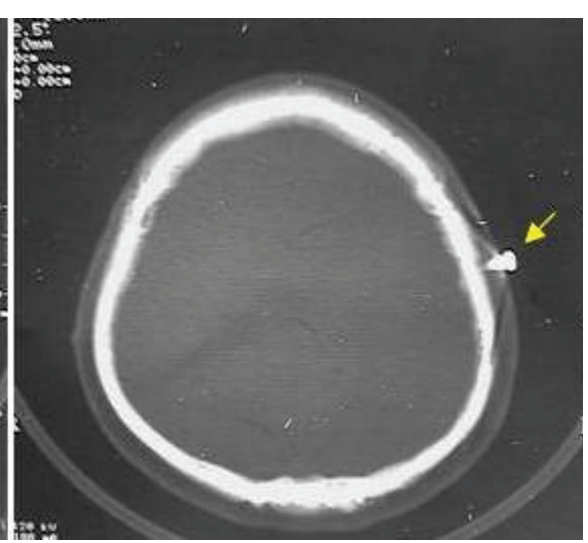


6). Nail guns were used in most of the suicide attempts with nails. There are very few cases of attempted suicide by hammering nails in the literature. To our knowledge, there are only five publications about nail hammering (711). The reason for such a small number of cases is the necessity of using both hands to commit suicide and the necessity to continue suicide in spite of pain. There are also cases of penetrating brain injuries caused by nails which may be the result of a punishment.

In the literature, it is observed that patients who attempt suicide with this method usually have psychiatric disorders and repeatedly attempt suicide. As a matter of fact, our patient attempted suicide 4 times in total and died at the last attempt. Our patient was treated with the diagnosis of severe schizophrenia but discontinued his treatment. Patients who commit suicide may choose different methods despite all difficulties. Also, our patient has learned from the internet that the dominant hemisphere of the brain was frequently on the left side and then hammered the nail to the left side of the head. Easy access to information can sometimes be used by patients in a negative direction. CT is the most useful tool for initial investigation of penetrating injuries to the brain. It has been stated that magnetic resonance imaging can be useful in the assessment of injuries caused by non-magnetic materials (4). Although some studies reported that X-ray was useless, it is easier to understand the size and route of these materials on X-ray images (4). In the presence of suspicion of vascular injury due to the location of the material, angiography may provide more reliable results (12). Direct removal of the nail in surgical treatment, or removal by craniotomy or craniectomy is still controversial. We recommend performing small craniectomy under general anesthesia around the penetrating material and then performing mini craniotomy like a ring with leaving the material in the middle. After the craniotomy is performed, the dura mater is opened around the penetrating material and the penetrating object is pulled out in a controlled manner. If bleeding occurs from any area, this method will allow for necessary intervention. In addition, in this way, inwardly penetrating bone tissues and dirty wound edges can be debrided. Particular attention should be paid to early and late complications and if there is a cortical injury, antiepileptic treatment should be started immediately. To prevent cerebrospinal fluid fistula, the dura mater should be sutured in a watertight fashion and a broad-spectrum antibiotic therapy should be initiated. Tetanus prophylaxis should also be performed. It is recommended that once clinical stability is achieved, the patients should be referred to the psychiatry department for the treatment of the psychiatric disorder.

Cranial nail injuries are extremely rare and should be treated with caution after radiological evaluation. After surgical treatment, management of underlying psychiatric disorder and subsequent closer observation of the patient is momentous.

\section{Authorship Contributions}

Surgical and Medical Practices: A.Ö., S.D., M.Y. Concept: A.Ö., O.Y. Design: A.Ö., S.D. Data Collection or Processing: A.Ö., O.K. Analysis or Interpretation: A.Ö., S.D., O.Y. Literature Search: A.Ö., O.K. Writing: A.Ö., O.K.

Conflict of Interest: No conflict of interest was declared by the authors.

Financial Disclosure: The authors declared that this study received no financial support.

\section{References}

1. Scarfo GB, Mariotini A, Palma L. Oculocerebral perforating trauma by foreign objects:diagnosis and surgery. J Neurosurgery 1990;34:111-6.

2. Yano H, Nishimura G, Sakamato K, Tanaka M, Dazai S, Hirano $H$. An intracranial wooden foreign body without norological findings:case report. J Trauma 1995;38:830-2.

3. Pan R, Wang J. Cranial penetration injury caused by a reinforcing steel bar. Chin J Traumatol 2001;4:185-6.

4. Cemil B, Tun K, Yiğenoğlu O, Kaptanoğlu E. Attempted suicide with screw penetration into the cranium. Ulus TRavma Acil Cerrahi Derg 2009;15:624-7.

5. Johansson B, Eriksson A. Suicide by Driving an Awl into the Brain. Am J Forensic Med Pathol 1988;9:331-3.

6. Karabatsou K, Kandasami J, Rainov NG. Self-inflicted penetrating head injury in a patient with manic-depressive disorder. Am J Forensic Med Pathol 2005;26:174-6.

7. Musa S, Ba Simpson RH Hatfield B. Recurrent self-inflicted craniocerebral injury: case report and review of the literature. Br J Neurosurg 1997;11:564-9.

8. Hemphill RE. Attempted suicide by hammering a nail into the brain. S A fr Med J 1980;57:477-8

9. Green KA, Dickman CA, Smith KA, Kinder EJ, Zabramski JM. Self-inicted orbital and intracranial injury with a retained foreign body, associated with psychotic depression: case report and review. Surg Neurol 1993;40:499-503.

10. Spiers AS. Attempted suicide or hitting the nail on the head. Case report. J Fla Med Assoc 1994;81:822-3.

11. Ohaegbulam SC, Ojukwu JO. Unusual craniocerebral injuries from nailing. Surg Neurol 1980;14:393-5.

12. Du Trevou MD, Van Dellen JR. Penetrating stab wounds to the brain: the timing of angiography in patients presenting with the weapon already removed. Neurosurgery 1992;31:905-12. 